\title{
Genetic Analysis to Select Good Combiners for TYLCV-Tolerance and Yield Components in Tomato
}

\author{
Ahmed M.A. Mahmoud \\ Vegetable Crops Department, Faculty of Agriculture, Cairo University, Giza, Egypt \\ Corresponding author e-mail: ahmed.ali@agr.cu.edu.eg
}

\begin{abstract}
As an attempt to develop high-yielding and TYLCV-tolerant hybrids, this study was conducted using TYLCV-tolerant inbred lines F8: 802-5 ( $\left.\mathrm{P}_{1}\right)$; F8: 802-21 $\left(\mathrm{P}_{2}\right)$ and selection of CLN3498E $\left(\mathrm{P}_{3}\right)$ and TYLCVsusceptible cvs Ace 55VF $\left(\mathrm{P}_{4}\right)$, Super Strain $\mathrm{B}\left(\mathrm{P}_{5}\right)$ and Castlerock $\left(\mathrm{P}_{6}\right)$. A line $\times$ tester mating system was carried out under greenhouse conditions through the 2012 winter planting to produce tolerant $\times$ susceptible hybrids. Nine $F_{1}$ hybrids and their parents were evaluated for TYLCV tolerance, yield and fruit quality under natural infection of TYLCV by whitefly-mediated virus inoculations under field conditions during the 2013 and 2014 fall plantings. Mid-parent hterosis (H), heterobeltiosis (BPH), potence ratio (P), and combining ability effects were estimated for the evaluated traits. The variances due to combining abilities showed that additive gene action played the predominant role in controlling TYLCV-tolerance and yield traits. The hybrids of parent $\mathrm{P}_{1}$, in addition to $\mathrm{P}_{2} \times \mathrm{P}_{4}$ exhibited the maximum $\mathrm{H}$ and BPH for early (EY) and total yield (TY)/plant under TYLCV-infection. The hybrids of $\mathrm{P}_{1}$ were exhibited the maximum negative significant $\mathrm{H}$ of TYLCV mean score. TYLCV-tolerant parent $\mathrm{P}_{1}$ was a good combiner for TYLCV mean score, EY/plant and TY/plant traits, while, TYLCV-susceptible parent $\mathrm{P}_{4}$ was a good combiner for each of TYLCV-mean score, EY/plant, TY/plant, average fruit weight (AFW), and fruit TSS content traits. The TYLCV-tolerant cross $\mathrm{P}_{2} \times \mathrm{P}_{4}$ was a good combination for TYLCV mean score, TY/plant, AFW, fruit firmness, and fruit TSS content traits, while TYLCV-tolerant cross $\mathrm{P}_{1} \times \mathrm{P}_{4}$ was a good combination for TYLCV mean score, EY/plant, TY/plant and fruit titarable acidity content traits.
\end{abstract}

Keywords: Tomato, TYLCV, yield, heterosis, heterobeltiosis, potence ratio, combining ability.

\section{Introduction}

Tomato (Solanum lycopersicum L.) is an important solanaceous fruit vegetable grows in both field and greenhouses around the world for its nutritional and economic value. Egypt is one of the major tomato production countries and ranked fourth with production about $8,533,803$ tons with an average of 16.83 tons/fed grown on 507,014.3 feddens in 2013 (http://faostat.fao.org/).

Tomato is subject to several biotic stresses including viral diseases which are responsible for significant tomato production losses over world. Among the viral diseases, tomato yellow leaf curl disease (TYLCD) is one of the serious tomato production constraints in tropical and subtropical regions of the world, including Egypt and it can totally destroy tomato yield (Picó et al., 1999). The disease is induced by a number of Begomovirus species (Family: Geminiviridae), among them, Tomato yellow leaf curl virus (TYLCV), which is widely spread worldwide (Fauquet and Stanley, 2005). The management of TYLCD in tomato is difficult, expensive, and with limited options. The use of virus-resistant/tolerant tomato cvs is considered the best way to reduce yield losses inflected by TYLCD, protects the income of the farmers, and reduce the spread of the virus. As their use is perhaps the easiest, safest, most practical, and best environmentfriendly method for controlling this viral disease.
No resistance to TYLCD was found in cultivated $S$. lycopersicum (Picó et al., 1999; Pilowsky and Cohen, 2000). Hence, wild tomato species have been screened for their reaction to virus and a number of TYLCV-resistant/tolerant accessions of wild species identified (Hassan et al., 2009). Genetic studies on TYLCV resistance have revealed different genetic control mechanisms for various sources of resistance in wild species and in most cases multiple genes are involved in the resistance (Hassan et al., $1984 \mathbf{a \& b}$; Pico et al., 1996; Hassan and Abdel-Ati, 1999; Abdel-Ati, 2008 and Mahmoud, 2010). Thus, breeding programs have been based mainly on the transfer of resistance genes from wild accessions into the cultivated tomato. After more than 20 years breeding efforts by research centers, universities, and seed companies, advanced breeding lines with high levels of resistance from S. chilense, S. habrochaites, $S$. galapagense, $S$. peruvianum, and $S$. pimpinellifolium have been developed by multiple breeding programs and are used extensively to breed high quality $\mathrm{F}_{1}$ hybrids (Lapidot and Friedmann, 2002 and Czosnek, 2007).

In Egypt, TYLCV-resistant/tolerant cvs are mostly imported, as the production of TYLCV resistant/tolerant local tomato cvs are nil. It appears that focusing attention on breeding tomato for TYLCV resistance/tolerance is highly desirable for the production and release of local hybrids. There are 
few breeding attempts to produce TYLCVresistant/tolerant inbreed lines and hybrids. Hassan et al. (1987) developed a resistant breeding line from an interspecific cross of $S$. lycopersicum cv. Mortelglan $\times S$. peruvianum CMV sél INRA (PI $126926 \times$ PI 128648-6). A moderately resistant breeding line (line 44) was derived from introgression of resistance genes from $S$. galapagense with the commercial cv. Pakmor B (Moustafa and Nakhla, 1990). Moustafa et al. (2005) used 7 true-breeding tomato lines having high resistance to TYLCV and good fruit quality characters to produce 8 hybrids were evaluated along with their parents and two controls, i.e., cv. Castlerock and the hybrid E 448 (Al-Qods). All evaluated hybrids showed high level of TYLCV resistance, and all of them were not significantly different from the check hybrid E 448. Mahmoud (2010) selected four TYLCV-tolerant genotypes from S. lycopersicum and Solanum sp. and used them in a half-diallel crossing program to produce tolerant $x$ tolerant $F_{1}$ 's and in a line $\times$ tester crossing program to produce tolerant $\times$ susceptible $F_{1}$ 's. TYLCVresistance in these selections were polygenic with partial dominance of resistance over susceptible. Thus, TYLCV-tolerance was highly in tolerant $x$ tolerant $F_{1}$ 's and moderate in tolerant $\times$ susceptible $F_{1}$ 's. Some of produced hybrids showed good fruit yield and quality.

The success of a breeding program relies heavily on the choice of the used parents and the resulting progeny for commercial exploitation. Greater success can be achieved through planned execution with judicious choice of parents based on genetic divergence and combining ability. Therefore, prediction of the magnitude and frequency of heterotic crosses assumes greater importance. It is increasingly realized that crosses between divergent parents usually produce greater heterosis than those between closely related ones (Moll and Stuber, 1971). However, Moll et al. (1965) observed heterosis increased with increased divergence, but extremely divergent crosses resulted in decrease in heterosis. Further, Cress (1966) demonstrated genetic diversity necessary for significant heterosis but insufficient to guarantee the same.

Test crosses for general and specific combining ability must be primarily achieved. General combining ability (GCA) reveals the existence of additive gene effects, while specific combining ability (SCA) reveals non-additive gene effects and additive $\times$ dominance and dominance $\times$ dominance interactions. Information about GCA effects are beneficial in choosing best combiner parents and SCA effects information reveal best cross combinations for further judgment. Judicious application of information relevant to heterosis and SCA are fruitful for selecting best hybrids for desired traits (Moore and Currence 1950). High heterosis for various commercial and vegetative traits has been reported by several workers in tomato (Fu et al., 2014). However, little information is available for heterosis and genetic combining ability for TYLCVresistance/tolerance in tomato (Moustafa et al., 2005; Shankarappa et al., 2008; Mahmoud, 2010 and Singh et al., 2014).

Among the various methods to estimate combining abilities, top cross (inbred $\times$ variety) or line $\times$ tester method (Kempthorne, 1957) is very useful in screening the parental lines by attempting less number of crosses. As an attempt to produce TYLCV-tolerant and good yield hybrids, this study was carried out to evaluate 3 lines (TYLCV-tolerant females), 3 testers (TYLCV-susceptible males) and their 9 crosses for TYLCV-tolerance and yield components traits. Crosses tested for GCA and SCA combining abilities and the heterosis, heterobeltosis and potence ratio were determined.

\section{Materials and Methods}

A tomato breeding program for TYLCVresistance/tolerance was carried out at the Agricultural Experiment Station (AES) of the Faculty of Agriculture, Cairo University, Giza, Egypt. Recurrent selection of TYLCVresistant/tolerant genotypes from segregating generations of highly tolerant hybrid cv. TH99802 was applied under field conditions during the 2005 to 2011 fall plantings. Two highly TYLCV-tolerant tomato inbreed lines, viz., F8: 802-5 and F8: 802-21 were selected from this breeding program in addition to highly tolerant selection from inbreed line CLN2498E, which developed for ToLCV-resistance by introgressed ToLCV-resistance gene $T y$ - 2 from $S$. habrochaites by AVRDC, Taiwan (AVRDC, 2000). These TYLCV-tolerant inbred lines have low yield of medium-sized fruits (approximately, 40-60 g). The resistant/tolerant genotypes should possess other desirable economic traits to make them viable at commercial level. Therefore, large fruited cvs Ace 55 VF, Castlercok and Super Strain B were selected to produce tolerant $\times$ susceptible $F_{1}$ 's by a line $\times$ tester mating system to study the magnitude of TYLCVtolerance and fruit yield traits. Crossing was carried out in greenhouse at AES during the 2012 winter planting. Nine $F_{1}$ hybrids and their parents were evaluated for TYLCV-resistance/tolerance, yield and fruit quality under field conditions during the 2013 and 2014 fall plantings at private farm in ElKhalidiya village, Ibshiwiaa, El-Fayoum Governate, Egypt.

Seeds of these genotypes were sowed in each of the two fall seasons on the first of July in speedlings trays under net-house conditions. Five weeks-old seedlings were field-transplanted in a randomized complete block design with three replicates. Each experimental unit (EU) consisted of 2 rows, $1.2 \mathrm{~m}$ wide $\times 4 \mathrm{~m}$ long. Plants were set $50 \mathrm{~cm}$ apart and 
subjected to the common agricultural practices without applying insecticides.

TYLCV is transmitted to plants naturally by the whitefly (Bemisia tabaci Genn. and B. argentifollii (B. tabaci biotype B); Homoptera: Aleyrodidae) which was widely flourishes from April through November, with a peak from August to October (Shaheen, 1983). Therefore, virus infection was enhanced by natural viruliferous whitefly infestation in the field plots without using insecticides. Data on TYLCV-resistance/tolerance was recorded for individual plants 3 months after transplanting on a 15 scale, depending on the severity of TYLCV symptoms as follows: 1: no symptoms appearing on the plant, 2: slight symptoms on plant top, 3: moderate symptoms, 4: severe symptoms on the entire plant, and 5: severe symptoms and plant stunting. Individual plant ratings of each accession were added and divided by the number of evaluated plants to obtain the corresponding mean disease score.

Average fruit weight (AFW - mean weight of 15 fruits), early yield (EY- the first three harvests) and total yield (TY - all the collected fruits) per plant were determined. Samples of 10 ripe fruits representing each EU were picked for analysis of fruit quality traits; viz., fruit firmness (FF), total soluble solids (TSS) and titratable acidity (TA) contents. Fruit firmness was determined by using a food pressure tester (Force Gauge Model M4-200) Mark-10 (Series 4) as a mean of three readings were taken for each fruit by pushing the pentameter needle slowly at near the shoulder, blossom end and equatorial plane. An extract was obtained by blending and filtering flesh of each fruit sample. TSS was determined by using a hand refractometer. TA was ascertained using $0.1 \mathrm{~N} \mathrm{NaOH}$ solution and phenolphthalein as indicator (AOAC, 1990).

\section{Statistical analysis}

Data obtained were statistically analyzed using combined analysis by MSTAT-C v. 2.1 (Michigan State University, Michigan, USA) and mean comparisons were based on the least significant differences (LSD) test (Steel and Torrie, 1981).

\section{Analysis of combining abilities}

The combined mean data were subjected to combined ability analysis of variance. Combining ability analysis was carried out according to Singh and Choudhary (1979) fixed effect model using the following formula:

$$
X_{i j k}=\boldsymbol{\mu}+\mathbf{G}_{\mathbf{i}}+\mathbf{G}_{\mathbf{j}}+\mathbf{S}_{\mathbf{i j}}+\mathbf{E}_{\mathbf{i j k}}
$$

Where $\mu$, general mean; $\mathrm{G}_{\mathrm{i}}$, GCA effect of $\mathrm{i}$ line (female parent); $\mathrm{Gj}$, GCA effect of $\mathrm{j}$ tester (male parent); $S_{i j}$, SCA effects of hybrids with the $i$ lines and $\mathrm{j}$ tester; $\mathrm{E}_{\mathrm{ijk}}$, error associated with the $i$ observation at the plot; $i=1,2 \ldots$ (1) (number of lines); $\mathrm{j}=1,2 \ldots \mathrm{t}$ (number of testers); and $\mathrm{k}=1,2$, $3 \ldots \mathrm{r}$ (number of replications).

\section{Estimation of heterosis}

Mid-parent heterosis $(\mathrm{H})$ and heterobeltiosis (betterparent heterosis - BPH) for the different studied characters were calculated using the following equations (Mather and Jinks, 1971):

$$
\begin{aligned}
H & =\frac{\overline{F_{1}}-M P}{M_{P}} \times 100 \\
B P H & =\frac{\overline{F_{1}}-\overline{B P}}{\overline{B P}} \times 100
\end{aligned}
$$

Where, $\overline{\mathrm{F}_{1}}$ mean value of hybrid, MP mid-parent value, and $\overline{\mathrm{BP}}$ mean value of the better parent.

\section{Estimation of potence ratio}

Potence ratio $(\mathrm{P})$ was used to determine the direction of dominance according to Smith (1952) as follows:

$$
\mathbf{P}=\frac{\overline{\mathbf{F}_{1}}-\mathbf{M P}}{1 / 2\left(\overline{\mathbf{P}_{2}}-\overline{\mathbf{P}_{1}}\right)}
$$

Where, $\overline{\mathrm{P}_{1}}$ : mean of the smaller parent, and $\overline{\mathrm{P}_{2}}$ : mean of the larger parent.

The absence of dominance was assumed when the difference between the parents was significant and $\overline{\mathbf{F}_{\mathbf{1}}}-\mathbf{M P}$ was not significant. Complete dominance was assumed when $\mathrm{P}$ equaled to or did not differ from \pm 1.0 . Meanwhile, partial dominance was considered when $\mathrm{P}$ was between +1.0 and -1.0 , but was not equal to zero. Over dominance (heterosis) was assumed when $\mathrm{P}$ exceeded \pm 1.0.

\section{Results and Discussion}

The genetic diversity and genetic information are indispensable to develops efficient breeding strategies. The genetic diversity indicates to the allelic divergence between genotypes, while, the genetic information indicates to the inheritance and behavior of major quantitative traits associated with yield, quality or any economic trait. The success of a breeding program relies mainly on the choice of appropriate parents and the breeding method. The common approach of choosing the parents on the basis of performance, adaptation and genetic variability does not necessarily lead to useful results. This is because of the differential ability of the parents which depends on the complex interactions among the genes and cannot be judged by performance alone (Allard, 1960). The parents which perform well in the cross combinations are of great importance to the breeders. Therefore, prediction of the magnitude and frequency of heterotic crosses assumes greater importance.

\section{Analysis of variance}

Analysis of variance (Table 1) revealed high significant differences due to genotypes (parents and hybrids) and hybrids for all the studied traits under TYLCV-infection. Also, variance due to parents (lines and testers) was highly significant for all traits except TSS trait. This indicates to the genetic diversity among parents for the evaluated traits which justifies the selection of parents especially tester parents for this study and helps in the selection of suitable parents for utilization in breeding programs and is necessary to observe heterosis in $F_{1}$ 
hybrids (Singh et al., 2014). Variance due to parents versus hybrids was also highly significant for all traits except TYLCV mean score (Table 1). This reveals significant differences between parents and hybrids for fruit yield and quality traits and indicating a substantial amount of hybrid vigor in crosses. Substantial variability among the crosses and their significant average heterosis could be attributed to significance of variance due to line $\times$ tester interaction indicating the involvement of dominant and/or epistatic gene action in the inheritance of all the characters under study.

Table 1. Analysis of variance (ANOVA) of combining ability for six tomato parents and their line $\times$ tester crosses for various studied characters.

\begin{tabular}{llllccccc}
\hline S.V. & df & $\begin{array}{l}\text { TYLCV } \\
\text { mean score }\end{array}$ & $\begin{array}{l}\text { Early } \\
\text { yield }\end{array}$ & $\begin{array}{c}\text { Total } \\
\text { yield }\end{array}$ & $\begin{array}{l}\text { Average } \\
\text { fruit weight }\end{array}$ & $\begin{array}{l}\text { Fruit } \\
\text { firmness }\end{array}$ & TSS & $\begin{array}{l}\text { Titratable } \\
\text { acidity }\end{array}$ \\
\hline Replication & 2 & 0.01 & 0.0003 & 0.02 & 2.76 & 0.001 & 0.02 & 0.010 \\
Genotypes & 14 & $2.25^{* *}$ & $0.077^{* *}$ & $1.79^{* *}$ & $1029.33^{* *}$ & $0.022^{* *}$ & $0.28^{* *}$ & $0.045^{* *}$ \\
Parents (P) & 5 & $5.87^{* *}$ & $0.078^{* *}$ & $2.01^{* *}$ & $2357.46^{* *}$ & $0.025^{* *}$ & 0.05 & $0.050^{* *}$ \\
Hybrids (H) & 8 & $0.25^{* *}$ & $0.015^{* *}$ & $0.10^{* *}$ & $304.95^{* *}$ & $0.019^{* *}$ & $0.19^{* *}$ & $0.028^{* *}$ \\
P vs H & 1 & 0.08 & $0.565^{* *}$ & $14.14^{* *}$ & $183.70^{* *}$ & $0.029^{* *}$ & $2.12^{* *}$ & $0.157^{* *}$ \\
Error & 28 & 0.02 & 0.001 & 0.03 & 14.32 & 0.001 & 0.03 & 0.003 \\
\hline
\end{tabular}

*Significant (P $\leq 0.05)$ and ${ }^{* *}$ highly significant $(\mathrm{P} \leq 0.01)$.

\section{Mean performance of the evaluated genotypes}

Significant differences were found among the evaluated genotypes (hybrids and their parents) for yield and fruit traits under natural TYLCV-infection (Table 2). TYLCV-tolerant lines showed highly TYLCV-tolerant without significant differences among them and were significantly more TYLCVtolerant than susceptible testers. Evaluated $\mathrm{F}_{1} \mathrm{~s}$ showed moderate TYLCV-tolerance and their TYLCV-mean scores ranged from 2.23 to 3.14 with significant differences among them. The highest level of TYLCV-tolerance was noted in the hybrid $\mathrm{P}_{1}$ $\times \mathrm{P}_{4}$, which scored 2.23 followed by $\mathrm{P}_{2} \times \mathrm{P}_{4}, \mathrm{P}_{1} \times \mathrm{P}_{5}$, and $\mathrm{P}_{1} \times \mathrm{P}_{6}$, with mean scores ranging from 2.55 to 2.68 , with significant differences among them.

Table 2. Combined mean performance of nine $F_{1}$ tomato hybrids and their parents for TYLCV mean score, yield and fruit traits.

\begin{tabular}{|c|c|c|c|c|c|c|c|}
\hline Genotype & $\begin{array}{c}\text { TYLCV } \\
\text { mean } \\
\text { score }^{\mathrm{z}}\end{array}$ & $\begin{array}{c}\text { Early } \\
\text { yield } \\
\text { (kg/plant) }\end{array}$ & $\begin{array}{c}\text { Total } \\
\text { yield } \\
\text { (kg/plant) }\end{array}$ & $\begin{array}{c}\text { Average } \\
\text { fruit } \\
\text { weight } \\
\text { (g) }\end{array}$ & $\begin{array}{c}\text { Fruit } \\
\text { firmness } \\
\left(\mathbf{k g} / \mathbf{c m}^{2}\right)\end{array}$ & $\begin{array}{l}\text { TSS } \\
(\%)\end{array}$ & $\begin{array}{c}\text { Titratable } \\
\text { acidity } \\
\text { (mg citric } \\
\text { acid/100 g } \\
\text { FW) }\end{array}$ \\
\hline \multicolumn{8}{|c|}{ TYLCV-tolerant lines } \\
\hline $\mathrm{F}_{8}: 802-5\left(\mathrm{P}_{1}\right)$ & $1.69 \mathrm{i}$ & $0.54 \mathrm{fg}$ & $2.51 \mathrm{f}$ & $43.33 \mathrm{~g}$ & $0.46 \mathrm{fg}$ & $4.13 \mathrm{ef}$ & $0.99 \mathrm{c}-\mathrm{f}$ \\
\hline $\mathrm{F}_{8}: 802-21\left(\mathrm{P}_{2}\right)$ & $1.56 \mathrm{i}$ & $0.52 \mathrm{~g}$ & $2.78 \mathrm{~d}-\mathrm{f}$ & $42.90 \mathrm{~g}$ & $0.50 \mathrm{ef}$ & $3.79 \mathrm{~g}$ & 0.94 ef \\
\hline CLN2498E sel $\left(\mathrm{P}_{3}\right)$ & $1.52 \mathrm{i}$ & $0.59 \mathrm{de}$ & 2.73 ef & 60.41 ef & $0.53 \mathrm{de}$ & $3.88 \mathrm{fg}$ & $1.07 \mathrm{bc}$ \\
\hline \multicolumn{8}{|c|}{ TYLCV-susceptible testers } \\
\hline Ace $55 \mathrm{VF}\left(\mathrm{P}_{4}\right)$ & $3.78 \mathrm{c}$ & $0.32 \mathrm{~h}$ & $1.40 \mathrm{~g}$ & $113.6 \mathrm{a}$ & $0.39 \mathrm{~h}$ & $4.27 \mathrm{c}-\mathrm{e}$ & $0.76 \mathrm{~g}$ \\
\hline Super Strain B $\left(\mathrm{P}_{5}\right)$ & $4.12 \mathrm{~b}$ & $0.25 \mathrm{i}$ & $1.27 \mathrm{~g}$ & $87.76 \mathrm{~b}$ & $0.59 \mathrm{c}$ & $4.13 \mathrm{ef}$ & $0.96 \mathrm{~d}-\mathrm{f}$ \\
\hline Castlerock $\left(\mathrm{P}_{6}\right)$ & $4.45 \mathrm{a}$ & $0.23 \mathrm{i}$ & $0.94 \mathrm{~h}$ & $84.02 \mathrm{bc}$ & $0.65 \mathrm{a}$ & $3.84 \mathrm{~g}$ & $0.75 \mathrm{~g}$ \\
\hline \multicolumn{8}{|c|}{ Line $\times$ tester hybrids } \\
\hline $\mathrm{P}_{1} \times \mathrm{P}_{4}$ & $2.23 \mathrm{~h}$ & $0.79 \mathrm{a}$ & $3.36 \mathrm{a}$ & $65.59 \mathrm{de}$ & $0.42 \mathrm{gh}$ & $4.49 \mathrm{bc}$ & $1.10 \mathrm{~b}$ \\
\hline $\mathrm{P}_{1} \times \mathrm{P}_{5}$ & $2.57 \mathrm{~g}$ & $0.66 \mathrm{~b}$ & $2.98 \mathrm{~b}-\mathrm{e}$ & $56.90 \mathrm{f}$ & $0.60 \mathrm{bc}$ & $4.47 \mathrm{~b}-\mathrm{d}$ & $0.93 \mathrm{ef}$ \\
\hline $\mathrm{P}_{1} \times \mathrm{P}_{6}$ & $2.68 \mathrm{fg}$ & $0.64 \mathrm{~b}-\mathrm{d}$ & $2.99 \mathrm{~b}-\mathrm{e}$ & $66.07 \mathrm{de}$ & $0.62 \mathrm{a}-\mathrm{c}$ & $4.31 \mathrm{c}-\mathrm{e}$ & $1.02 \mathrm{~b}-\mathrm{e}$ \\
\hline $\mathrm{P}_{2} \times \mathrm{P}_{4}$ & $2.55 \mathrm{~g}$ & $0.65 \mathrm{bc}$ & $3.33 \mathrm{a}$ & $80.11 \mathrm{c}$ & 0.49 ef & $5.10 \mathrm{a}$ & $1.01 \mathrm{~b}-\mathrm{f}$ \\
\hline $\mathrm{P}_{2} \times \mathrm{P}_{5}$ & $3.04 \mathrm{de}$ & 0.58 ef & $3.01 \mathrm{~b}-\mathrm{d}$ & 60.15 ef & $0.58 \mathrm{~cd}$ & $4.58 \mathrm{~b}$ & $1.25 \mathrm{a}$ \\
\hline $\mathrm{P}_{2} \times \mathrm{P}_{6}$ & $2.90 \mathrm{ef}$ & $0.60 \mathrm{c}-\mathrm{e}$ & $2.86 \mathrm{c}-\mathrm{e}$ & $61.77 \mathrm{~d}-\mathrm{f}$ & $0.64 \mathrm{ab}$ & $4.47 \mathrm{~b}-\mathrm{d}$ & $1.04 \mathrm{~b}-\mathrm{d}$ \\
\hline $\mathrm{P}_{3} \times \mathrm{P}_{4}$ & 2.89 ef & $0.66 \mathrm{~b}$ & $3.21 \mathrm{ab}$ & $88.51 \mathrm{~b}$ & $0.51 \mathrm{e}$ & $4.29 \mathrm{c}-\mathrm{e}$ & $0.93 \mathrm{f}$ \\
\hline $\mathrm{P}_{3} \times \mathrm{P}_{5}$ & $3.14 \mathrm{~d}$ & $0.55 \mathrm{e}-\mathrm{g}$ & $3.12 \mathrm{a}-\mathrm{c}$ & $67.37 \mathrm{~d}$ & $0.62 \mathrm{a}-\mathrm{c}$ & $4.23 \mathrm{de}$ & $1.00 \mathrm{c}-\mathrm{f}$ \\
\hline $\mathrm{P}_{3} \times \mathrm{P}_{6}$ & $2.95 \mathrm{de}$ & $0.58 \mathrm{ef}$ & $2.87 \mathrm{c}-\mathrm{e}$ & $64.50 \mathrm{de}$ & $0.66 \mathrm{a}$ & $4.16 \mathrm{e}$ & $1.02 \mathrm{~b}-\mathrm{f}$ \\
\hline LSD $_{0.05}$ & 0.24 & 0.05 & 0.26 & 6.33 & 0.05 & 0.25 & 0.09 \\
\hline
\end{tabular}

${ }^{\mathrm{z} D i s a s e}$ scores: 1, symptomless; 2, slight; 3: moderate; 4: severe symptoms, and 5: very severe symptoms and stunting plant.

For yield traits, as reaction to TYLCV-tolerance, tolerant parent CLN2498E sel produced the highest significant EY/plant followed by tolerant parents $\mathrm{F}_{8}$ :
802-5 and $F_{8}$ : 802-21 with significant difference among them (Table 2). None significant differences showed among tolerant parents for TY/plant and 
gave TY ranged from 2.51 to $2.78 \mathrm{~kg} /$ plant. Yield (early and total) of susceptible parents was affected by TYLCV-infection and scored significantly low yield compared with tolerant parents. With regard to the evaluated hybrids, hybrids performance was generally better than parental performance especially susceptible for yield traits (Table 2). Early Yield/plant for hybrids ranged from $0.55 \mathrm{~kg}$ to 0.79 $\mathrm{kg}$. The highest significant EY/plant was produced by the hybrid $\mathrm{P}_{1} \times \mathrm{P}_{4}$. Hybrids $\mathrm{P}_{1} \times \mathrm{P}_{5}, \mathrm{P}_{3} \times \mathrm{P}_{4}, \mathrm{P}_{2} \times$ $\mathrm{P}_{4}$, and $\mathrm{P}_{1} \times \mathrm{P}_{6}$ were the second in this respect without significant differences among them. While, $\mathrm{TY} /$ plant for the evaluated hybrids ranged from 2.86 $\mathrm{kg}$ to $3.36 \mathrm{~kg}$. The hybrids $\mathrm{P}_{1} \times \mathrm{P}_{4}, \mathrm{P}_{2} \times \mathrm{P}_{4}, \mathrm{P}_{3} \times \mathrm{P}_{4}$, and $\mathrm{P}_{3} \times \mathrm{P}_{5}$ produced the highest significant TY/plant among the evaluated genotypes (Table 2).

The susceptible parents (testers) produced large-sized fruits and tester $\mathrm{cv}$. Ace $55 \mathrm{VF}$ produced the heaviest fruits (113.6g), followed by Super Strain B (87.8 g) and Castlerock $(84 \mathrm{~g})$. The average fruit weight of tolerant parents ranged from 42.9 to $60.4 \mathrm{~g}$, while, the average fruit weight of the evaluated hybrids ranged from 60.15 to $88.51 \mathrm{~g}$ (Table 2).

For fruit quality traits, Fruit firmness of the evaluated genotypes ranged from 0.39 (cv. Ace 55VF) to 0.66 $\mathrm{kg} / \mathrm{cm}^{2}\left(\mathrm{P}_{3} \times \mathrm{P}_{6}\right)$. Fruits of cv. Castlerock and hybrids $\mathrm{P}_{3} \times \mathrm{P}_{6}, \mathrm{P}_{2} \times \mathrm{P}_{4}, \mathrm{P}_{1} \times \mathrm{P}_{6}$, and $\mathrm{P}_{3} \times \mathrm{P}_{5}$ had more firmness compared with other evaluated genotypes without significant differences among them. Fruit TSS of parents ranged from 3.79 (F8: 802-21) to $4.27 \%$ (cv. Ace 55VF). While, fruit TSS of the evaluated hybrids ranged from 4.31 to 5.10. Some crosses were superior for the TSS $\left(\mathrm{P}_{2} \times \mathrm{P}_{4}\right.$ followed by $\mathrm{P}_{2} \times \mathrm{P}_{5}, \mathrm{P}_{1} \times \mathrm{P}_{4}, \mathrm{P}_{1} \times \mathrm{P}_{5}$, and $\mathrm{P}_{2} \times \mathrm{P}_{6}$ ). Fruit TA content of the evaluated germplasm ranged from 0.75 (cv. Castlerock) to $1.25 \mathrm{mg}$ citric acid/100 g FW ( $\mathrm{P}_{2}$ $\times \mathrm{P}_{5}$ ). The cross $\mathrm{P}_{2} \times \mathrm{P}_{5}$ have the highest TA content (1.25 mg citric acid/100 $\mathrm{g}$ fresh weight) followed by $\mathrm{P}_{1} \times \mathrm{P}_{4}, \mathrm{P}_{2} \times \mathrm{P}_{6}, \mathrm{P}_{1} \times \mathrm{P}_{6}$, and $\mathrm{P}_{2} \times \mathrm{P}_{4}$ (Table 2).

\section{Heterosis and potence ratio estimations for $F_{1}$ hybrids}

Significant efforts have been made for exploitation of heterosis in different yield contributing traits to find the feasible cross for the production of $F_{1}$ hybrids. The hybrids with high heterotic effects may offer better chances for identification of desirable pure lines in the following advanced generations as compared to hybrids with low heterosis (Sharif $\boldsymbol{e t}$ al., 2001). The estimates of heterosis, relative to mid parental values (Tables 3 \& 4) reflected significant effects in desirable directions in all $\mathrm{F}_{1}$ hybrids for EY/plant and $\mathrm{TY} /$ plant traits; in seven hybrids for FF and TSS content; in six hybrids for TA content and in three hybrids for TYLCV mean score. No hybrid exhibited significant heterosis in desired direction over mid-parent for AFW. The mid-parent heterosis varied from -18.5 to $11.4 \%$ for TYLCV mean score, 31.7 to $83.7 \%$ for EY/plant, 49 to $73.1 \%$ for TY/plant, -16.4 to $2.4 \%$ for AFW, -16.4 to $3.8 \%$ for FF, 5.2 to $24.3 \%$ for fruit TSS content and -4.8 to 31.6 for fruit TA content.

The estimates of BPH percentages (Tables $3 \& 4$ ) reflected desired significant effects in three $F_{1}$ hybrids for fruit TA content trait; in five hybrids for fruit TSS content; in six hybrids for TY/plant; and in seven hybrids for EY/plant. None of the hybrids expressed significant $\mathrm{BPH}$ in desired direction for each of TYLCV-mean score, AFW, and FF traits. The extent of BPH varied from 31.8 to $106.6 \%$ for TYLCV-mean score, -6.7 to $46.3 \%$ for EY/plant, 3.4 to $34 \%$ for TY/plant, -42.3 to $-21.4 \%$ for AFW; -10.6 to 5.1 for FF, 0.5 to 17.3 for fruit TSS content, and 13.3 to $29.8 \%$ for fruit TA content.

Potence ratio of TYLCV-mean score trait varied from -0.49 to 0.21 and they were between \pm 1 , where six crosses had low negative values (Table 3), indicating partial-dominance of TYLCV-tolerance with the exception of two crosses which showed partial dominance of TYLCV-susceptibility. The estimated values of potence ratio showed that in most $\mathrm{F}_{1}$ crosses had a positive nature for EY/plant, TY/plant, FF, TSS, and TA traits (Tables $3 \& 4$ ). Early yield/plant expressed over dominance in 7 crosses and partial dominance in 2 crosses. Potence ratio of $\mathrm{TY} /$ plant was more than \pm 1 for all crosses (over dominance). In respect to $\mathrm{FF}$, potence ratios were more than +1 for three crosses (overdominance) and between \pm 1 for six crosses (partial dominance).

Table 3. Heterosis percentages $\left(\mathrm{H}\right.$, mid parent and $\mathrm{BPH}$, better parent) and potence ratio $(\mathrm{P})$ of nine $\mathrm{F}_{1}$ tomato hybrids for TYLCV mean score and early and total yield traits.

\begin{tabular}{|c|c|c|c|c|c|c|c|c|c|}
\hline \multirow[b]{2}{*}{$\operatorname{Cross}^{\mathrm{z}}$} & \multicolumn{3}{|c|}{ TYLCV-mean score } & \multicolumn{3}{|c|}{ Early yield } & \multicolumn{3}{|c|}{ Total yield } \\
\hline & $\mathbf{H}$ & BPH & $\mathbf{P}$ & $\mathbf{H}$ & BPH & $\mathbf{P}$ & $\mathbf{H}$ & BPH & $\mathbf{P}$ \\
\hline $\mathbf{P}_{1} \times \mathbf{P}_{4}$ & $-18.5^{* *}$ & $31.8^{* * *}$ & -0.49 & $83.7^{* *}$ & $46.3^{* *}$ & 3.27 & $72.0^{* *}$ & $34.0^{* *}$ & 2.54 \\
\hline $\mathbf{P}_{1} \times \mathbf{P}_{5}$ & $-11.7^{* *}$ & $52.0^{* *}$ & -0.28 & $67.8^{* *}$ & $22.2^{* *}$ & 1.82 & $57.8^{* *}$ & $19.0^{* *}$ & 1.77 \\
\hline $\mathbf{P}_{1} \times \mathbf{P}_{6}$ & $-12.6^{* *}$ & $58.8^{* *}$ & -0.28 & $67.8^{* *}$ & $19.1^{* *}$ & 1.66 & $73.1^{* *}$ & $19.1^{* *}$ & 1.61 \\
\hline $\mathbf{P}_{2} \times \mathbf{P}_{4}$ & -4.8 & $62.4^{* *}$ & -0.12 & $54.6^{* *}$ & $25.2^{* *}$ & 2.32 & $59.7^{* *}$ & $20.2^{* *}$ & 1.82 \\
\hline $\mathbf{P}_{2} \times \mathbf{P}_{5}$ & 6.7 & $93.7^{* *}$ & 0.15 & $52.8^{* *}$ & $12.9^{* *}$ & 1.49 & $49.0^{* *}$ & 8.8 & 1.33 \\
\hline $\mathbf{P}_{2} \times \mathbf{P}_{6}$ & -3.6 & $85.1^{* *}$ & -0.07 & $62.3^{* *}$ & $16.8^{* *}$ & 1.60 & $54.2^{* *}$ & 3.4 & 1.10 \\
\hline $\mathbf{P}_{3} \times \mathbf{P}_{4}$ & $9.0^{*}$ & $89.8^{* *}$ & 0.21 & $45.3^{* *}$ & $11.8^{* *}$ & 1.51 & $55.4^{* *}$ & $17.6^{* *}$ & 1.72 \\
\hline $\mathbf{P}_{3} \times \mathbf{P}_{5}$ & $11.4^{* *}$ & $106.6^{* * *}$ & -0.25 & $31.7^{* *}$ & -6.7 & 0.77 & $55.7^{* *}$ & $14.2^{* *}$ & 1.53 \\
\hline $\mathbf{P}_{3} \times \mathbf{P}_{6}$ & -1.4 & $93.4^{* *}$ & 0.03 & $41.5^{* *}$ & -2.2 & 0.93 & $56.4^{* *}$ & 5.3 & 1.16 \\
\hline
\end{tabular}

Highly significant $(\mathrm{P} \leq 0.01)$ and *ignificant $(\mathrm{P} \leq 0.05)$. 
${ }^{z} \mathrm{P}_{1}, \mathrm{~F}_{8}: 8-2-5 ; \mathrm{P}_{2}, \mathrm{~F}_{8}: 802-21 ; \mathrm{P}_{3}$, TYLCV-tolerant selection of CLN2498E; testers $\mathrm{P}_{4}$, cv. Ace 55 VF; $\mathrm{P}_{5}, \mathrm{cv}$. Super Strain B; and $\mathrm{P}_{6}$, cv. Castlerock.

Table 4. Heterosis percentages $\left(\mathrm{H}\right.$, mid parent and $\mathrm{BPH}$, better parent) and potence ratio $(\mathrm{P})$ of nine $\mathrm{F}_{1}$ tomato hybrids for fruit traits.

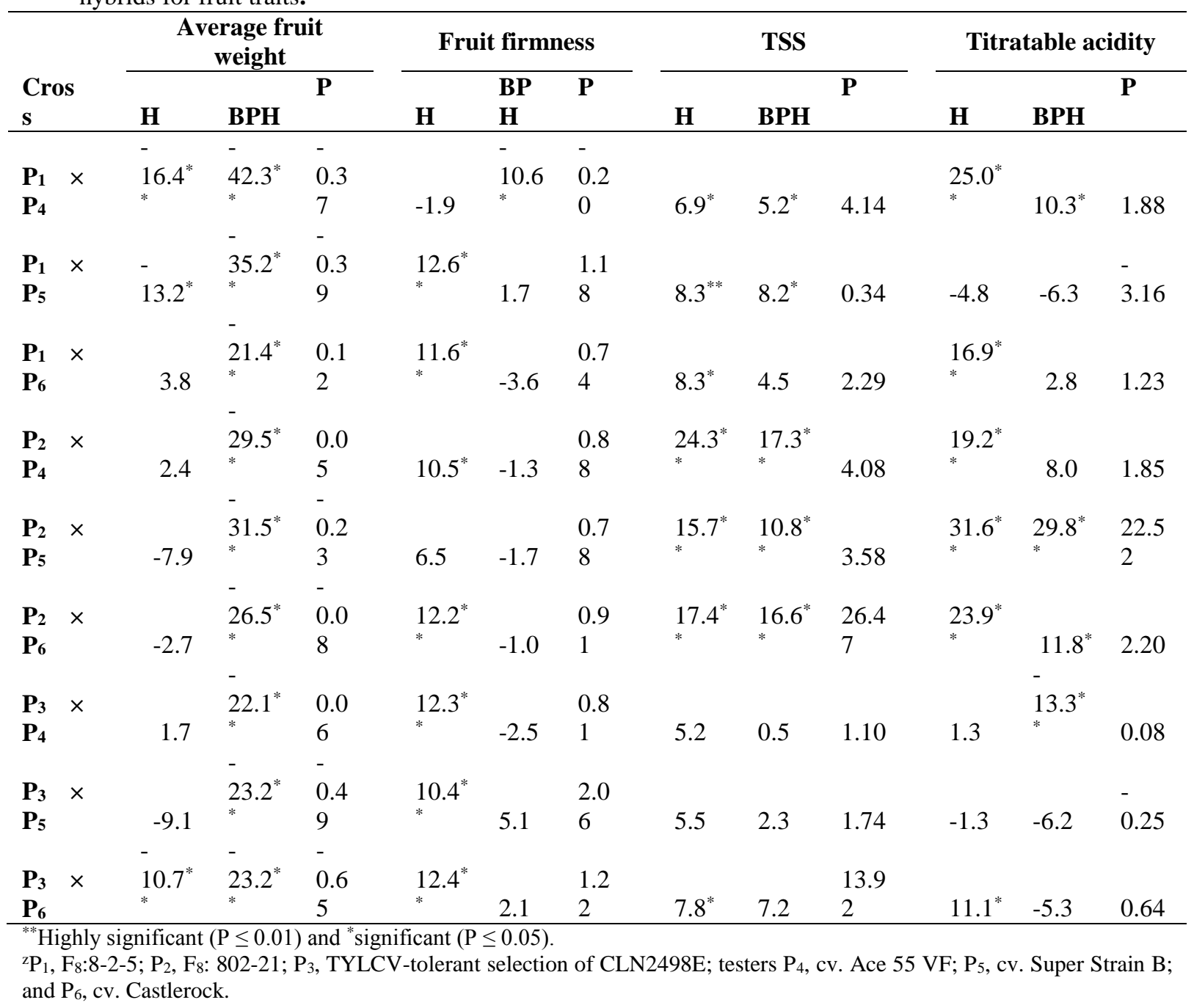

In case of fruit TSS content, eight crosses expressed over dominance and only one cross expressed partial dominance. In case of fruit TA content, six crosses expressed over dominance and three crosses expressed partial dominance. On the contrary, the estimated values of potence ratios in most crosses were negative for AFW trait. Negative values of $\mathrm{P}$ indicated the presence of various degrees of recessiveness, i.e. partial- to under-recessiveness.

The recent trend in tomato breeding has been towards development of hybrids to meet the specific uses, especially disease resistance coupled with high yield. The parents for the present investigation were selected on the basis of their performance with a view to develop TYLCV-tolerant and highly yielding hybrids. The means of $F_{1}$ crosses were intermediate between both parents in TYLCV-tolerance trait (Table 2). Also, the negative values of $\mathrm{H}$ and $\mathrm{P}$ for TYLCV-mean score trait showed that TYLCVtolerance was partial dominance (Table 3). Partial dominance for TYLCV-tolerance was reported in AVRDC tolerant lines H24, FLA591-15, and FLA456-4 (Chomdej et al., 2007) and some TYLCV-tolerant selections of tomato (Mahmoud, 2010). Also, Abdel-Ati (2008) found partial dominance for TYLCV-tolerance in 3 crosses susceptible $\times$ tolerant crosses. Therefore, Shankarappa et al. (2008) found that some of tomato hybrids (resistant $\times$ susceptible) have most heterotic values and were highly resistant to ToLCV. On the contrary, Mazyad et al (2007) found that TYLCV-tolerance in line Favi-9 was partially recessive.

The positive values of $\mathrm{H}, \mathrm{BPH}$, and $\mathrm{P}$ for $\mathrm{EY}$ and TY traits indicated the involvement of the additive dominance gene action in the inheritance of these traits. Xiao et al. (1995) found that dominance is the major genetic basis of heterosis for yield components. Significant positive heterosis ( $\mathrm{H}$ and $\mathrm{BPH})$ were reported for this trait in several works 
(Vidyasagar et al., 1997; Hannan et al., 2007b; Sherpa et al., 2014 and Mahmoud and ElEslamboly, 2015). Hence, hybrid breeding can be used efficiently to improve yield in tomato (Hannan et al., 2007b). General, The increased yield in these hybrids may be due to increased TYLCV-tolerance and to the high yielding parents selected for hybridization as suggested by Courtney and Peirce (1979) and Kurian et al. (2001). Heterosis over better parent for AFW was negative in all tomato hybrids. These results are in broad conformity with the findings of Wahb-Allah (2008), Souza et al. (2012), and Solieman et al. (2013). The hybrids of parent $\mathrm{P}_{1}$, in addition to $\mathrm{P}_{2} \times \mathrm{P}_{4}$ exhibited the maximum relative $\mathrm{H}$ and $\mathrm{BPH}$ for $\mathrm{EY}$ and $\mathrm{TY}$ under TYLCV-infection and the hybrids of $\mathrm{P}_{1}$ exhibited the maximum negative significant $\mathrm{H}$ of TYLCV mean score (Table 3).

In tomato, mere breeding for enhanced yield is not important unless it is qualified by the quality requirements desired by the consumers. Concerning FF and fruit contents of TSS and AAC traits, the results demonstrated the presence of different degrees of dominance; i.e., partial- to overdominance, for the high values over low ones in each character; which seemed to be involved in the inheritance of these characters. These results were in agreement with those obtained by Garg et al. (2008) who suggested that various degrees of dominance effects (from partial- to over-dominance) played important roles on the inheritance of these characters. Positive and significant $\mathrm{H}$ and $\mathrm{BPH}$ in tomato for $\mathrm{FF}$ and fruit contents of TSS and AAC traits has been reported by many investigators (Shalaby, 2008 and 2012; Singh and Asati, 2011 and Solieman et al., 2013).

\section{Combining ability analysis}

The analyses of variance for combining ability components presented in Table 5. Variance due to lines (GCA-lines) was significant for TYLCV-mean score, EY, and fruit TSS content traits. Variance due to testers (GCA-testers) showed significance $(\mathrm{P} \leq 0.05)$ for TYLCV-mean score and EY traits and highly significance $(\mathrm{P} \leq 0.01)$ for $\mathrm{TY}$ and $\mathrm{FF}$ traits. While, variance due to line $\times$ tester $(\mathrm{SCA})$ was highly significant for AFW and fruit TA content traits (Table 5) and was significant for EY and FF traits. Thereby indicating those testers were divergent from lines which justify the choice of testers. Further, the mean sum of squares attributed to the tester (male) and line (female) parents of hybrids provide a measure of their GCA and the interaction between the male and female parents provide a measure of SCA.

Table 5. Analysis of variance of combining ability for 3 lines $\times 3$ testers tomato crosses for various characters.

\begin{tabular}{|c|c|c|c|c|c|c|c|c|}
\hline S.V. & df & $\begin{array}{l}\text { TYLCV } \\
\text { mean score }\end{array}$ & $\begin{array}{l}\text { Early } \\
\text { yield }\end{array}$ & $\begin{array}{l}\text { Total } \\
\text { yield }\end{array}$ & $\begin{array}{l}\text { Average } \\
\text { fruit } \\
\text { weight }\end{array}$ & $\begin{array}{l}\text { Fruit } \\
\text { firmness }\end{array}$ & TSS & $\begin{array}{l}\text { Titratabl } \\
\text { e acidity }\end{array}$ \\
\hline Replication & 2 & 0.01 & 0.0003 & 0.02 & 2.76 & 0.001 & 0.02 & 0.010 \\
\hline Hybrids (H) & 8 & $0.25^{\text {** }}$ & $0.015^{* *}$ & $0.10^{* *}$ & $304.95^{* *}$ & $0.019^{* *}$ & $0.19^{\text {** }}$ & $0.028^{* *}$ \\
\hline Lines (L-GCA) & 2 & $0.59^{*}$ & $0.026^{*}$ & 0.01 & 255.12 & 0.006 & $0.48^{*}$ & 0.035 \\
\hline Testers (T-GCA) & 2 & $0.33^{*}$ & $0.028^{*}$ & $0.36^{* *}$ & 716.01 & $0.067^{* *}$ & 0.18 & 0.006 \\
\hline $\mathbf{L} \times \mathbf{T}(\mathrm{SCA})$ & 4 & 0.04 & $0.002^{*}$ & 0.02 & $124.33^{* *}$ & $0.002^{*}$ & 0.05 & $0.036^{* *}$ \\
\hline Error & 28 & 0.02 & 0.001 & 0.03 & 14.32 & 0.001 & 0.02 & 0.003 \\
\hline Contribution of $\mathbf{L}$ & & 58.54 & 44.70 & 1.42 & 20.91 & 7.42 & 63.42 & 31.45 \\
\hline Contribution of $T$ & & 32.95 & 47.73 & 88.20 & 58.70 & 88.03 & 23.07 & 5.26 \\
\hline \multicolumn{9}{|l|}{ Contribution of $\mathrm{L} \times$} \\
\hline $\mathbf{T}$ & & 8.50 & 7.57 & 10.38 & 20.39 & 4.55 & 13.50 & 63.28 \\
\hline GCA variance $\left(\delta^{2} \mathrm{~g}\right)$ & 5 & 0.0115 & 0.0007 & 0.0045 & 10.0342 & 0.0010 & 0.0077 & -0.0004 \\
\hline SCA variance $\left(\delta^{2}\right)$ & 8 & 0.0071 & 0.0005 & 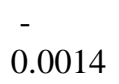 & 36.6720 & 0.0004 & 0.0095 & 0.0110 \\
\hline$\delta^{2}{ }_{g}: \delta^{2} s$ & & 1.6210 & 1.3660 & 3.1508 & 0.2736 & 2.4010 & 0.8163 & -0.0378 \\
\hline$\delta^{2}{ }_{A}$ & & 0.1039 & 0.0062 & 0.0403 & 90.3080 & 0.0087 & 0.0696 & -0.0037 \\
\hline$\delta^{2} D$ & & 0.0285 & 0.0020 & $\begin{array}{l}- \\
0.0057\end{array}$ & 146.6879 & 0.0016 & 0.0379 & 0.0439 \\
\hline
\end{tabular}

*Significant $(\mathrm{P} \leq 0.05),{ }^{* *}$ highly significant $(\mathrm{P} \leq 0.01)$ and ${ }^{\mathrm{ns}}$ non-significant.

The contribution of lines as compared to testers was more for TYLCV-mean score and fruit TSS content traits. Testers contributed more to the total sum squares for EY, TY, AFW, and fruit TSS traits. The line $\times$ tester interaction was higher than their parents for only fruit TA content trait (Table 5). These results showed that lines, testers and the interaction lines $\times$ testers brought much variation in the expression of the studied traits. The results of the 
present study revealed large variation between parents and hybrids for the evaluated traits.

The variance due to GCA $\left(\delta^{2}\right)$ was higher than variance due to $\operatorname{SCA}\left(\delta_{\mathrm{s}}^{2}\right)$ and $\delta^{2} \mathrm{~g}: \delta^{2}{ }_{\mathrm{s}}$ was more than one for the all studied traits except AFW, TSS and TA contents characters (Table 5). Also, additive genetic variance $\left(\delta_{\mathrm{A}}^{2}\right)$ was larger than dominance genetic variance $\left(\delta^{2}\right)$ for these traits. These results suggesting the preponderance of additive gene action controlling these traits and reflecting the importance of individual plant selection to improve TYLCV mean score, yield and FF traits by increase the frequency of favorable alleles. Recurrent selection is a breeding method that increases the frequency of favorable alleles and identifies the superior combinations by repeated crossing and selection could be the best method to exploit the additive gene effects (Jensen, 1970). The use of mass selection with concurrent random mating (Redden and Jensen, 1974) or restricted recurrent selection by mating the most desirable segregants followed by selection (Shende et al., 2012) might be useful breeding strategies for the improvement of these traits governed by both additive and non-additive types of gene action.

Additive gene effect was reported in regulating the inheritance of TYLCV-reistance/tolerance and total yield/plant with prevalence of dominant gene effect (Mahmoud, 2010). Singh et al. (2014) mentioned that additive and non-additive gene effects played important roles in inheritance of yield components under ToLCV-infection and additive gene effects were found to be more important than non-additive gene effects. Also, similar findings were observed in some investigations under normal conditions of tomato production (Hannan et al., 2007 a\&c; Garg et al., 2007 and 2008; Andrade et al., 2014 and Mahmoud and El-Eslamboly, 2015), where additive gene effects appeared more important than non-additive gene action for fruit yield/plant. On other hand, Hannan et al. (2007 a\&c) and Solieman (2009) reported that non-additive gene effects played a great role on the inheritance of TY trait. Also, Saleem et al. (2009) found that the ratio of additive to dominance variances was less than one and these reflected the predominant role of nonadditive gene action. The difference in the results of various investigations may be attributed to differences of breeding material and to genotype $\times$ environments. Concerning on FF, Garg et al. (2008) found that additive gene effects were more important than non-additive gene effects in the inheritance of this trait and similar findings were observed in this study.

Higher values of $\sigma^{2}$ s than $\sigma_{\mathrm{g}}^{2}$ for AFW, TSS, and fruit TA content traits suggesting the preponderance of non-additive gene action controlling these characters (Table 5). Also, $\sigma^{2}$ D was larger than $\sigma^{2}{ }_{\mathrm{A}}$ for theses traits. These results are supported by $\sigma^{2}{ }_{\text {gca }} / \sigma_{\text {sca }}^{2}$ ratio which was smaller than unity (Table
5). Heterosis breeding is the best possible options for improving these traits by accumulate the genes from superior gene combinations interacting in a favorable manner. However, selection will slow genetic improvement, where that selection of superior plants, in terms of these traits should be postponed to later generation by making selections among the recombinants within the segregating populations (Kalloo, 1991). Similar result was reported by ELGabry et al. (2014), who found that non-additive gene effects was more important for AFW and TSS traits.

\section{General combining ability effects}

Estimation of GCA provides basic and important information for exploiting genetic potential of parents for development of superior and elite lines. As expression of significant and high GCA effects of a parent line reflect the presence of favorable additive genes with additive genetic effects that lead to selection in early generations for developing widely adapted hybrids (Roy $\boldsymbol{e t}$ al., 2002). A parent with higher positive significant GCA effects is considered as a good general combiner. In the present study, no single parent was found to be a good general combiner for all studied characters (Table 6). The good combiners for TYLCVtolerance, which showed the significant negative values of GCA effects (desirable form), were $\mathrm{P}_{1}$ from lines and $\mathrm{P}_{4}$ from testers. The average fruit weight (AFW) displayed a negative GCA value for all parents, except $\mathrm{P}_{3}$ and $\mathrm{P}_{4}$ (Table 6). This is in accordance with the good combiner for fruit weight studied by Mahmoud (2010) and Singh et al. (2014). For EY/plant, only two parents $\left(P_{1}\right.$ - tolerant and $\mathrm{P}_{4}$ - susceptible) exhibited positive significant GCA effects. While, TY/plant, none of the parents were found significant, except male parent $\mathrm{P}_{4}$, which expressed their significant value for GCA effect. Also, $\mathrm{P}_{1}$ exhibited insignificant desirable GCA effect for TY/plant. Thus, these parents may be good combiners for yield capacity (Table 6). These results are in accordance with the studies of Mahmoud (2010) and Singh et al. (2014). From the estimations of combining abilities, the results in Table 6 exhibited that the best combiners, which showed the significant positive values of GCA effects (desirable form), for FF were $\mathrm{P}_{3}, \mathrm{P}_{5}$ and $\mathrm{P}_{6}$; for TSS were $\mathrm{P}_{2}$ and $\mathrm{P}_{4}$ and for TA was $\mathrm{P}_{2}$. The remaining parents exhibited negative or non-significant values of GCA effects for the evaluated traits. These findings were supported by the study of Mahmoud (2010) and Singh et al. (2014). Different parental lines and testers expressing significant positive and negative and also non-significant GCA effects in respect of yield and component traits in tomato have also been reported earlier by Rattan et al. (2007), Sharma $\boldsymbol{e t}$ al.(2007) and Saidi et al. (2008).

\section{Specific combining ability effects}


Accumulation of additive gene effects for desired characters is the basic need for hybrid development and hybrids with high SCA effects for various traits involving either one or both of the parents with good GCA indicating the preponderance of additive genetic effects. Hybrids with significant and positive SCA involving the parents with low or nonsignificant GCA showed the worth of non-additive genetic effects. In the present study, the best hybrid combinations that reflected the significant positive values of SCA effects, which means that the parents of this particular cross can combine well to produce a hybrid with a high general performance; were found to be those of the $\mathrm{F}_{1}$ hybrids $\mathrm{P}_{1} \times \mathrm{P}_{6}$ and $\mathrm{P}_{3} \times \mathrm{P}_{4}$ for AFW and $\mathrm{P}_{1} \times \mathrm{P}_{4}$ and $\mathrm{P}_{2} \times \mathrm{P}_{5}$ for fruit TA content (Table 7).

Table 6. General combining ability (GCA) effects for different characters of line $\times$ tester tomato crosses.

\begin{tabular}{|c|c|c|c|c|c|c|c|}
\hline Parent $^{\mathrm{z}}$ & $\begin{array}{c}\text { TYLCV } \\
\text { mean score }\end{array}$ & $\begin{array}{l}\text { Early } \\
\text { yield }\end{array}$ & $\begin{array}{l}\text { Total } \\
\text { yield }\end{array}$ & $\begin{array}{l}\text { Average fruit } \\
\text { weight }\end{array}$ & $\begin{array}{c}\text { Fruit } \\
\text { firmness }\end{array}$ & TSS & $\begin{array}{c}\text { Titratable } \\
\text { acidity }\end{array}$ \\
\hline \multicolumn{8}{|l|}{ GCA lines } \\
\hline $\mathbf{P}_{1}$ & $-0.28^{* *}$ & $0.06^{* *}$ & 0.03 & $-5.03^{* *}$ & $-0.024^{* *}$ & -0.02 & -0.02 \\
\hline $\mathbf{P}_{2}$ & 0.06 & $-0.02^{*}$ & -0.02 & -0.54 & 0.003 & $0.24^{* *}$ & $0.07^{* *}$ \\
\hline $\mathbf{P}_{3}$ & $0.22^{* *}$ & $-0.04^{* *}$ & -0.01 & $5.57^{* *}$ & $0.026^{* *}$ & $-0.22^{* *}$ & $-0.05^{* *}$ \\
\hline SE gca lines & \pm 0.049 & \pm 0.009 & \pm 0.053 & \pm 1.261 & \pm 0.008 & \pm 0.051 & \pm 0.017 \\
\hline $\mathrm{SE}\left(\mathrm{g}_{\mathrm{i}}-\mathrm{g}_{\mathrm{j}}\right)$ lines & \pm 0.069 & \pm 0.012 & \pm 0.075 & \pm 1.784 & \pm 0.011 & \pm 0.072 & \pm 0.024 \\
\hline \multicolumn{8}{|l|}{ GCA testers } \\
\hline $\mathbf{P}_{4}$ & $-0.22^{* *}$ & $0.06^{* *}$ & $0.22^{* *}$ & $10.19^{* *}$ & $-0.096^{* *}$ & $0.15^{* *}$ & -0.02 \\
\hline $\mathbf{P}_{5}$ & $0.15^{* *}$ & $-0.04^{* *}$ & -0.04 & $-6.41^{* *}$ & $0.024^{* *}$ & -0.02 & 0.03 \\
\hline $\mathbf{P}_{6}$ & 0.07 & $-0.03^{* *}$ & $-0.17^{* *}$ & $-3.77^{* *}$ & $0.072^{* *}$ & $-0.13^{*}$ & -0.01 \\
\hline SE gca testers & \pm 0.049 & \pm 0.009 & \pm 0.053 & \pm 1.261 & \pm 0.008 & \pm 0.051 & \pm 0.017 \\
\hline SE $\left(g_{i}-g_{j}\right)$ testers & \pm 0.069 & \pm 0.012 & $\mathbf{\pm 0 . 0 7 5}$ & \pm 1.784 & \pm 0.011 & \pm 0.072 & \pm 0.024 \\
\hline
\end{tabular}

${ }^{* *}$ Highly significant $(P \leq 0.01)$ and *significant $(P \leq 0.05)$.

${ }^{z}$ Lines $\mathrm{P}_{1}, \mathrm{~F}_{8}: 8-2-5 ; \mathrm{P}_{2}, \mathrm{~F}_{8}: 802-21 ; \mathrm{P}_{3}$, TYLCV-tolerant selection of CLN2498E; testers $\mathrm{P}_{4}$, cv. Ace 55 VF; $\mathrm{P}_{5}$, cv. Super Strain B; and $\mathrm{P}_{6}$, cv. Castlerock.

Table 7. Specific combining ability (GCA) effects for different characters of nine tomato crosses.

\begin{tabular}{|c|c|c|c|c|c|c|c|}
\hline Cross $^{z}$ & $\begin{array}{c}\text { TYLCV } \\
\text { mean score }\end{array}$ & $\begin{array}{l}\text { Early } \\
\text { yield }\end{array}$ & $\begin{array}{l}\text { Total } \\
\text { yield }\end{array}$ & $\begin{array}{c}\text { Average } \\
\text { fruit weight }\end{array}$ & $\begin{array}{c}\text { Fruit } \\
\text { firmness }\end{array}$ & TSS & $\begin{array}{c}\text { Titratable } \\
\text { acidity }\end{array}$ \\
\hline $\mathbf{P}_{1} \times \mathbf{P}_{4}$ & -0.048 & 0.0281 & 0.03 & $-7.45^{* * *}$ & $-0.030^{*}$ & -0.09 & $0.10^{* *}$ \\
\hline $\mathbf{P}_{1} \times \mathbf{P}_{5}$ & -0.070 & -0.0007 & -0.08 & 0.46 & 0.024 & 0.07 & $-0.11^{* *}$ \\
\hline $\mathbf{P}_{1} \times \mathbf{P}_{6}$ & 0.118 & -0.0274 & 0.05 & $6.99^{* *}$ & 0.006 & 0.02 & 0.01 \\
\hline $\mathbf{P}_{2} \times \mathbf{P}_{4}$ & -0.065 & -0.0285 & 0.04 & 2.58 & 0.016 & 0.17 & $-0.07^{*}$ \\
\hline $\mathbf{P}_{2} \times \mathbf{P}_{5}$ & 0.063 & 0.0093 & -0.01 & -0.78 & -0.017 & -0.09 & $0.12^{* *}$ \\
\hline $\mathbf{P}_{2} \times \mathbf{P}_{6}$ & 0.002 & 0.0193 & -0.03 & -1.80 & 0.001 & -0.08 & -0.05 \\
\hline $\mathbf{P}_{3} \times \mathbf{P}_{4}$ & 0.113 & 0.0004 & -0.07 & $4.87^{*}$ & 0.014 & -0.09 & -0.03 \\
\hline $\mathbf{P}_{3} \times \mathbf{P}_{5}$ & 0.007 & -0.0085 & 0.09 & 0.32 & -0.006 & 0.02 & -0.01 \\
\hline $\mathbf{P}_{3} \times \mathbf{P}_{6}$ & -0.120 & 0.0081 & -0.02 & $-5.19^{*}$ & -0.007 & 0.07 & 0.04 \\
\hline S.E. $\left(s_{i j}\right)$ & \pm 0.084 & \pm 0.015 & \pm 0.092 & \pm 2.185 & \pm 0.013 & \pm 0.088 & \pm 0.029 \\
\hline S.E. $\left(\mathbf{S}_{\mathrm{ij}}-\mathbf{S}_{\mathbf{k j}}\right)$ & \pm 0.119 & \pm 0.022 & \pm 0.130 & \pm 3.090 & \pm 0.019 & \pm 0.124 & \pm 0.042 \\
\hline
\end{tabular}

Highly significant $(\mathrm{P} \leq 0.01)$ and *significant $(\mathrm{P} \leq 0.05)$.

${ }^{z}$ Lines $\mathrm{P}_{1}, \mathrm{~F}_{8}: 8-2-5 ; \mathrm{P}_{2}, \mathrm{~F}_{8}: 802-21 ; \mathrm{P}_{3}$, TYLCV-tolerant selection of CLN2498E; testers $\mathrm{P}_{4}$, cv. Ace 55 VF; $\mathrm{P}_{5}$, cv. Super Strain B; and $\mathrm{P}_{6}$, cv. Castlerock.

Non crosses exhibited significant desirable SCA effects for TYLCV-mean score, EY/plant, TY/plant, FF, and fruit TSS content (Table 7). However, there were some of crosses combinations exhibited desirable insignificant SCA effects for these traits. Where, the crosses $\mathrm{P}_{1} \times \mathrm{P}_{4}, \mathrm{P}_{1} \times \mathrm{P}_{5}$, and $\mathrm{P}_{2} \times \mathrm{P}_{4}$ were exhibited insignificant negative SCA effects for TYLCV-mean score. Five crosses $\left(\mathrm{P}_{1} \times \mathrm{P}_{4}, \mathrm{P}_{2} \times \mathrm{P}_{5}\right.$, $\mathrm{P}_{2} \times \mathrm{P}_{6}, \mathrm{P}_{3} \times \mathrm{P}_{4}$ and $\left.\mathrm{P}_{3} \times \mathrm{P}_{5}\right)$ were exhibited insignificant positive SCA effects for $\mathrm{EY} /$ plant, while for TY/plant, 4 crosses $\left(\mathrm{P}_{1} \times \mathrm{P}_{4}, \mathrm{P}_{1} \times \mathrm{P}_{6}, \mathrm{P}_{2} \times\right.$ $\mathrm{P}_{5}$, and $\mathrm{P}_{3} \times \mathrm{P}_{5}$ ) were exhibited insignificant SCA

According to the previous results of combining abilities, can be concluded that TYLCV-tolerant effects. For FF and fruit TSS content, five crosses exhibited insignificant positive SCA effects. Singh $\boldsymbol{e t}$ al. (2014) found that SCA effects do not contribute much to the improvement of tomato, where, most of the crosses showed SCA values were either nonsignificant or negative significant for various evaluated traits under ToLCV infection. Tiwari et al. (2011) mentioned that hybrid combinations, where at least one parent is a good general combiner, could be used to developing high yielding pure lines due to presence of additive gene action, even if these crosses showed non-significant SCA effects though. parent $\mathrm{P}_{1}$ was good combiner for $\mathrm{EY} /$ plant and TY/plant traits, while, TYLCV-susceptible parent $\mathrm{P}_{4}$ 
was a good combiner for TYLCV-mean score, $\mathrm{EY} /$ plant, TY/plant, AFW, and fruit TSS content traits. The TYLCV-tolerant cross $\mathrm{P}_{2} \times \mathrm{P}_{4}$ was good combination for EY/plant, TY/plant, AFW, FF, and fruit TSS content traits, while TYLCV-tolerant cross $\mathrm{P}_{1} \times \mathrm{P}_{4}$ was good combination for $\mathrm{EY} /$ plant, $\mathrm{TY} /$ plant, and TA content. These parents and hybrids could be utilized as good combiners and isolated to obtain desirable segregates for improving respective characters. This study was suggested the advantages of both types of variances, i.e. additive and nonadditive. Due to the presence of additive genetic variance, disease resistant capacity can be improved which may prove highly useful in yield improvement.

\section{References}

Abdel-Ati, K.E.A. (2008): Assessment and genetics of tomato yellow leaf curl virus resistance in cultivated and wild species. Ann. Agric. Sci., Moshtohor, 46 (2): 187-196.

Allard, R.W. (1960): Principles of Plant Breeding. John Wiley and Sons, Inc. New York, London. 485p.

Andrade, M.C.; da Silva, A.A.; Conrado, T.V.; Maluf, W.R.; Andrade T.M. and de Oliveira, C.M. (2014): Combining ability of tomato lines in Saladette-type hybrids. Bragantia, Campinas 73 (3): 237-245.

AOAC, Association of Official Agricultural Chemists. (1990): Official Methods of Analysis. $15^{\text {th }}$ ed, Washington, D.C. USA.

AVRDC, Asian Vegetable Research and Development Center. (2000): Resistance to tomato yellow leaf curl in Thailand and Southeast Asia. Annual Report for 2000. Sahnhua, Taiwan, pp. 110-112.

Chomdej, O.; Chatchawankanpanich, O.; Kositratana, W. and Chunwongse, J. (2007): Response of resistant breeding lines of tomato germplasm and their progenies with seedathip3 to Tomato yellow leaf curl virus, Thailand isolate (TYLCTHV-[2]). Songklanakarin J. Sci. Techn. 29 (6): 1469-1477.

Courtney, W.H. and Peirce, L.C. (1979): Parent selection in tomato based on morphophysiological traits. HortScience 14: 458.

Cress, C.E. (1966): Heterosis of the hybrid related to gene frequency difference between two populations. Genetics 53: 269-274.

Czosnek, H. (2007): Tomato Yellow Leaf Curl Virus Disease: Management, Molecular Biology, Breeding for Resistance. Springer, Dordrecht, the Netherlands, 447p.

El-Gabry, M.A.H.; Solieman T.J.H. and Abido, A.I.A. (2014): Combining ability and heritability of some tomato (Solanum lycopersicum L.) cultivars. Sci. Hort. 167: 153-157.
Fauquet, C.M. and Stanley, J. (2005): Revising the way we conceive and name viruses below the species level: a review of geminivirus taxonomy calls for new standardized isolate descriptors. Arch. Virol. 150: 2151-2179.

Fu, D.; Xiao, M.; Hayward, A.; Fu, Y.; Liu, G. and Jiang, G. (2014): Utilization of crop heterosis: a review. Euphytica 197: 161-173.

Garg, N.; Cheema, D.S. and Dhatt, A.S. (2007): Combining ability analysis involving rin, nor and alc alleles in tomato under late planting conditions. Adv. Hort. Sci. 21 (2): 59-67.

Garg, N.; Cheema, D.S. and Dhatt, A.S. (2008): Genetics of yield, quality and shelf life characteristics in tomato under normal and late planting conditions. Euphytica 159: 275-288.

Hannan, M.M.; Manosh, K.B.; Mohammed, B.A.; Monzur, H. and Rafiul, I. (2007a): Combining ability analysis of yield and yield components in tomato (Lycopersicum esculentum Mill.). Turk. J. Bot. 31: 559-563.

Hannan, M.M.; Ahmed, M.B.; Razvy, M.A.; Karim, R.; Khatun, M.; Haydar, A.; Hossain, M. and Roy, U.K. (2007b): Heterosis and correlation of yield and yield components in tomato (Lycopersicon esculentum Mill.). Amer. Euras. J. Sci. Res. 2 (2): 146-150.

Hannan, M.M.; Ahmed, M.B.; Roy, U.K.; Razvy, M.A.; Haydar, A.; Rahman, M.A.; Islam, M.A. and Islam, R. (2007c): Heterosis, combining ability and genetics for brix \%, days to first fruit ripening and yield in tomato (Lycopersicon esculentum Mill.). Mid. East J. Sci. Res. 2 (3-4): 128-131.

Hassan, A.A. and Abdel-Ati, K.E.A. (1999): Genetics of tomato yellow leaf curl virus tolerance derived from Lycopersicon pimpinellifolium and Lycopersicon pennellii. Egypt. J. Hort. 26 (3): 323-338.

Hassan, A.A.; Laterrot, H.; Mazyad, H.M.; Moustafa, S.E. and Nakhla, M.K. (1987): Use of Lycopersicon peruvianum as a source of resistance to tomato yellow leaf curl virus. Egypt. J. Hort. 14 (2): 173-176.

Hassan, A.A.; Mazyad, H.M.; Moustafa, S.E.; Nassar, S.H.; Nakhla, M.K. and Sims, W.L. (1984a): Genetics and heritability of tomato yellow leaf curl virus tolerance derived from Lycopersicon pimpinellifolium. In: A New Era in Tomato Breeding. Institute for Horticultural Plant Breeding, Wageningen, the Netherlands, pp. 8187.

Hassan, A.A.; Mazyad, H.M.; Moustafa, S.E.; Nassar, S.H.; Nakhla, M.K. and Sims, W.L. (1984b): Inheritance of resistance to tomato yellow leaf curl virus derived from Lycopersicon cheesmanii and Lycopersicon hirsutum. HortScience 19 (4): 574-575.

Hassan, A.A.; Abdel-Ati, K.E.A. and Mahmoud, A.M.A. (2009): Tomato germplasm evaluation 
and selection for tomato yellow leaf curl virus resistance. Ann. Agric. Sci., Moshtohor 47 (2): 261-274.

Jensen, N.F. (1970): A diallel selective mating system for cereal breeding. Crop Sci. 10: 629635.

Kalloo, G. (1991): Genetic improvement of tomato. Monographs on Theroretical and Applied Genetics vol14. Springer-Verlag, New York, USA. 358 p.

Kempthorne, O. (1957): An Introduction to Genetic Statistics. John Wiley \& Sons, New York. pp 458-471.

Kurian, A.; Peter, K.V. and Rajan, S. (2001): Heterosis for yield components and fruit characters in tomato. J. Trop. Agric. 39: 5-8.

Lapidot, M. and Friedmann, M. (2002): Breeding for resistance to whitefly-transmitted geminiviruses. Ann. Appl. Biol. 140 (2): 109127.

Mahmoud, A.M.A. and El-Eslamboly, A.A.S.A. (2015): Genetic analysis to find suitable parents for development of cherry tomato hybrids under greenhouse conditions. Egypt., J. Plant Breed. 19 (1): 55-70.

Mahmoud, A.M.A. (2010): Genetic studies on tomato. Ph.D. Thesis, Fac. Agric., Cairo Univ., Egypt. 148p.

Mather, K. and Jinks, J.L. (1971): Biometerical Genetics. Cornell Univ. Press, Ithaca, NY, USA. 382p.

Mazyad, H.M.; Khalil, E.M.; Rezk, A.A.; AbdelHakem, M.A. and Aboul-Ata, A.E. (2007): Genetic studies on tomato yellow leaf curl begomovirus (TYLCV) resistance in Egypt: Sixpopulation analysis. Inter. J. Virol. 3 (2): 88-95.

Moll, R. and Stuber, C.W. (1971): Comparisons of response to alternative selection procedures initiated with two populations of maize ( $\mathrm{Zea}$ mays L.). Crop Sci. 11: 706-711.

Moll, R.H.; Lonnquist, J.H.; Fortuna, J.V. and Johnson, C.E. (1965): The relationship of heterosis and genetic divergence in maize. Genetics 52: 139-144.

Moore, J.F. and Currence, T.M. (1950): Combining ability in tomatoes. Minn. Agric. Expt. Sta. Tech. Bull. 188: 1-21.

Moustafa, S.E.S. and Nakhla, M.K. (1990): An attempt to develop a new tomato variety resistant to tomato yellow leaf curl virus (TYLCV). Assiut J. Agric. Sci. 21 (3): 167-183.

Moustafa, S.E.S.; Hassan, A.A.; Abdel-Ati, K.E.A. and Mohammed, A.A. (2005): Production of TYLCV-resistant tomato hybrids and their performance. In: $3^{\text {rd }}$ Conference on Recent Technologies in Agriculture, Cairo University, Egypt, pp. 607-625.

Picó, B.; Ferriol, M.; Diez, M.J. and Nuez, F. (1999): Developing tomato breeding lines resistant to tomato yellow leaf curl virus. Plant Breed. 118 (6): 537-542.

Picó, B.; Diez, M.J. and Nuez, F. (1996): Viral diseases causing the greatest economic losses to the tomato crop. II. The tomato yellow leaf curl virus-a review. Sci. Hort. 67 (3/4): 151-196.

Pilowsky, M. and Cohen, S. (2000): Screening additional wild tomatoes for resistance to the whitefly-borne tomato yellow leaf curl virus. Acta Physiol. Plant. 22 (3): 351-353.

Rattan, P.; Vidyasagar and Kumar, S. (2007): Line $\times$ tester analysis for combining ability studies involving bacterial wilt resistant genotypes of tomato (Lycopersicon esculentum Mill.). Haryana J. Hort. Sci. 36 (1-2): 158-161.

Redden, R.J. and Jensen, N.F. (1974): Mass selection and mating system in cereals. Crop Sci. 14: 345-350.

Roy, N.C.; Jettopujov, V.N. and Solanik, N.M. (2002): Combining ability for some agronomic characters in alfalfa (Medicago sativa L.). Pak. J. Agric. Res. 17 (4): 346-350.

Saidi, M.; Warade, S.D. and Prabu, T. (2008): Combining ability estimates for yield and its contributing traits in tomato (Lycopersicon esculentum). Inter. J. Agric. Biol. 10(2): 236-240.

Saleem, M.Y.; Asghar, M.; Haq, M.A.; Rafique, T.; Kamran, A. and Kahn, A.A. (2009): Genetic analysis to identify suitable parents for hybrid seed production in tomato (Lycopersicon esculentum Mill.). Pakistan J. Bot. 41 (3): 11071116.

Shaheen, A.H. (1983): Some ecological aspects on the whitefly Bemisia tabaci Grenn., the main insect vector transmitting tomato leaf curl virus diseases. Ann. Agric. Sci., Moshtohor 19: 453457.

Shalaby, T.A. (2008): Combining ability and heterosis in a half diallel cross of tomatoin north Egypt. J. Agric. Res. Kafr Elsheikh Univ. 34 (4): 1110-1125.

Shalaby, T.A. (2012): Line $\times$ tester analysis for combining ability and heterosis in tomato under late summer season conditions. J. Plant Prod., Mansoura Univ. 3(11): 2857-2865.

Shankarappa, K.S.; Sriharsha, Rangaswamy, K.T.; Aswathanarayana, D.S.; Prameela, H.A.; Kulkarni, R.S.; Muniyappa, V.; Rao, A.M. and Maruthi, M.N. (2008): Development of tomato hybrids resistant to tomato leaf curl virus disease in South India. Euphytica 164: 531539.

Sharif, A.; Bakhsh, A.; Arshad, M.; Haqqani, A.M. and Najma, S. (2001): Identification of genetically superior hybrids in chickpea (Cicer arietinum L.). Pakistan J. Bot. 33: 403-409.

Sharma P.; Vidyasagar and Bhardwaj, N. (2007): Combining ability in bacterial wilt resistant genotypes of tomato. Envir. Ecol. 25 (1): 196200. 
Shende, V.D.; Seth, T.; Mukherjee, S. and Chattopadhyay, A. (2012): Breeding tomato (Solanum lycopersicum L.) for higher productivity and better processing qualities. SABRAO J. Breed. Genet. 44 (2): 302-321.

Sherpa, P.; Seth, T.; Shende, V.D.; Pandiarana, N.; Mukherjee, S. and Chattopadhyay, A. (2014): Heterosis, dominance estimate and genetic control of yield and post-harvest quality traits of tomato. J. App. Nat. Sci., 6 (2): 625-632.

Singh, A.K. and Asati, B.S. (2011): Combining ability and heterosis studies in tomato under bacterial wilt condition. Bangladesh J. Agric. Res. 36 (2): 313-318.

Singh, R.K. and Choudhary, B.D. (1979): Biometrical Methods in Quantitative Genetic Analysis. Kalyani Publ., New Delhi.

Singh, R.K.; Rai, N.; Singh, M.; Singh, S.N. and Srivastava, K. (2014): Genetic analysis to identify good combiners for ToLCV resistance and yield components in tomato using interspecific hybridization. J. Genet. 93: 623629.

Smith, H.H. (1952): Fixing transgressive vigour in Nicotiana rustica. In: Heterosis. Iowa State College Press, Ames, IA.

Solieman, T.H.I. (2009): Diallel analysis of five tomato cultivars and estimation of some genetic parameters for growth and yield characters. Alex. Sci. Exch. J. 30 (2): 274-288.

Solieman, T.H.I.; El-Gabry, M.A.H. and Abido, A.I. (2013): Heterosis, potence ratio and correlation of some important characters in tomato (Solanum lycopersicum L.). Sci. Hort. 150: 25-30.

Souza, L.M.; Paterniani, M.E.A.G.Z.; Melo, P.C.T. and Melo, A.M.T. (2012): Diallel cross among fresh market tomato inbreeding lines. Hort. Bras. 30 (2): 246-251.

Steel, R.G.D. and Torrie, J.H. (1981): Principle and Procedure of Statistics. A Biometrical Approach. $2^{\text {nd }}$ ed, New York, NY, Mc-Graw-Hill Book Comp.

Tiwari, D.K.; Pandey, P.; Giri, S.P. and Dwivedi, J.L. (2011): Predication of gene action, heterosis and combining ability to identify superior rice hybrids. Inter. J. Bot. 7 (2): 126-144.

Vidyasagar, J.; Kumar and Chadha, S. (1997): Combining ability and gene action studies in tomato involving important bacterial wilt resistant lines. Him. J Agri. Res. 23 (1-2): 26-32.

Wahb-Allah, M.A. (2008): A diallel analysis of yield and yield components of some tomato genotypes grown in arid conditions. Zagazig J. Agric. Res. 35 (1): 19-32.

Xiao, J.; Li, J.; Yuan, L. and Tanksley, S.D. (1995): Dominance is the major genetic basis of heterosis in rice revealed by QTL analysis using molecular markers. Genetics 140 (2): 745-754. 